\title{
Commentary: Too old or not too old, that is the question: Video-assisted thoracoscopic surgery is (part of) the answer
}

\author{
Pierre-Emmanuel Falcoz, MD, PhD ${ }^{\mathrm{a}, \mathrm{b}, \mathrm{c}, \mathrm{d}}$ \\ From the a Strasbourg University School of Medicine, Strasbourg, France; ${ }^{\mathrm{b}}$ INSERM (French National Institute of \\ Health and Medical Research), Regenerative Nanomedicine, Strasbourg, France; ${ }^{c}$ Université de Strasbourg, \\ Faculté de Médecine et Pharmacie, Strasbourg, France; and ${ }^{\mathrm{d}}$ Department of Thoracic Surgery, Nouvel Hôpital \\ Civil, Hôpitaux Universitaires de Strasbourg, Strasbourg, France. \\ Disclosures: Author has nothing to disclose with regard to commercial support. \\ Received for publication Dec 5, 2018; accepted for publication Dec 6, 2018; available ahead of print Jan 17, 2018. \\ Address for reprints: Pierre-Emmanuel Falcoz, MD, PhD, Department of Thoracic Surgery, Nouvel Hôpital Civil, \\ Hôpitaux Universitaires de Strasbourg, 1 Place de l'Hôpital, BP 426, 67091 Strasbourg Cedex, France (E-mail: \\ pierre-emmanuel.falcoz@wanadoo.fr). \\ J Thorac Cardiovasc Surg 2019;157:1668-9 \\ 0022-5223/\$36.00 \\ Copyright (c) 2018 by The American Association for Thoracic Surgery \\ https://doi.org/10.1016/j.jtcvs.2018.12.022
}

\section{Age is an issue of mind over matter. If you don't mind, it doesn't matter.}

$$
\text { —Mark Twain (1835-1910) }
$$

In the present article, Dr Pages and associates ${ }^{1}$ seek to invasive approach, compared with open thoracotomy, on lobectomy in octogenarians. Because of the use of a welldocumented French national administrative database, inspired by the US Medicare System and called Programme de Médicalisation des Systèmes d'Informations, the authors concluded that video-assisted thoracoscopic surgery lobectomy significantly decreased postoperative mortality for octogenarians with localized lung cancer.

One might ask why the thoracic surgical community should be concerned with the findings of this study? Not only because this invigorating article addresses the issue of type and quality of thoracic surgery in octogenarians, which is an important topic in the modern era of thoracic surgery, but also because the current article reinforces concepts suggests important management considerations and fosters new ideas.

It is well known that age is, intrinsically, a risk factor of postoperative mortality, ${ }^{2}$ notably because of physiologic modifications (structural, functional, morphologic) of the elderly. ${ }^{3}$ When looking at our thoracic daily practice, both the Epithor (French) and the Surveillance, Epidemiology, and End Results (US) databases show the increased number of sublobar resections and the low level of lymph node samplings in octogenarians. ${ }^{4,5}$ One of the most important strengths of this article is its ability to demonstrate that lobectomy benefits octogenarians as much as it benefits younger patients. Nevertheless, it differs substantially from the recently published article on the Dutch Lung Surgery Database ${ }^{6}$ demonstrating a significant increase in address the absorbing question of the impact of a minimally

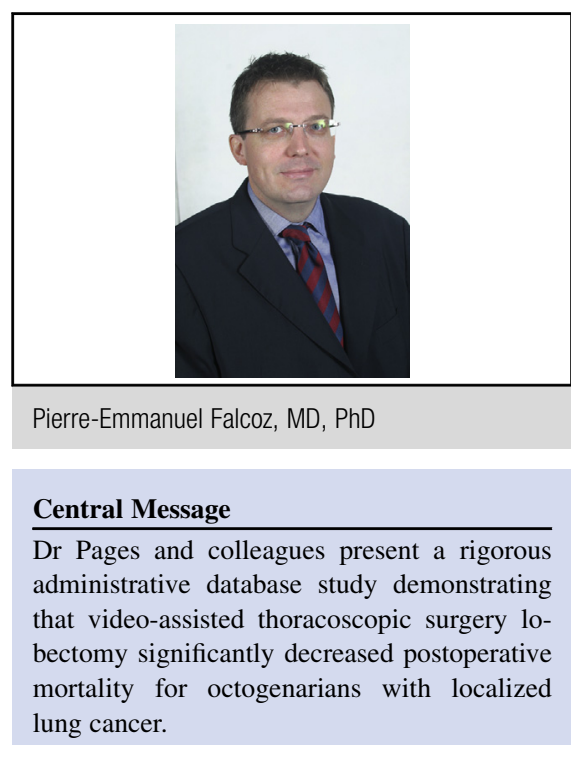

See Article page 1660. operative mortality among patients aged more than 80 years, although the incidence of complications was similar in all age groups. However, this apparent discrepancy only reflects a way of seeing things. Indeed, when analyzing the Society of Thoracic Surgeons General Thoracic Surgery Database in patients 65 years and older, Fernandez and colleagues ${ }^{7}$ demonstrated in patients with stage I an expected reduced survival with increasing age at diagnosis. Obviously, all age groups (65-69 years, 70-74 years, $75-79$ years, and $\geq 80$ years) have significantly worse survival than expected age-matched control subjects in the general population. If age and stage are clearly identified as the strongest predictors of long-term survival in elderly patients, ${ }^{8}$ procedure choice (video-assisted thoracoscopic surgery vs open) and type of approach (lobectomy vs sublobar) would also be considered as potentially modifiable predictors of longterm survival after lung cancer resection. In this context, the expected results of the STEPS study (NCT 02360761), which is the first randomized central trial comparing sublobar resection versus lobectomy on the surgical treatment of elderly patients with early-stage nonsmall cell lung cancer, might be of great management importance. Last but not least, this article also had the important merit of emphasizing some fundamental points: 
the rigorous selection of patients as the result of predictive risk modeling ${ }^{9}$ and the mandatory implementation of a fasttracking program.

For now, Dr Pages and colleagues ${ }^{1}$ are to be congratulated for their contribution to this area. From the standpoint of medical care, their results will certainly affect future patient management.

\section{References}

1. Pagès PB, Mariet AS, Madelaine L, Cottenet J, Abou Hana A, Quantin C, et al. Impact of video-assisted thoracic surgery approach on postoperative mortality after lobectomy in octogenarians. J Thorac Cardiovasc Surg. 2019;157:1660-7.

2. Bernard A, Rivera C, Pages PB, Falcoz PE, Vicaut E, Dahan M. Risk model of in-hospital mortality after pulmonary resection for cancer: a national database of the French Society of Thoracic and Cardiovascular Surgery (Epithor). J Thorac Cardiovasc Surg. 2011:141:449-58.

3. Meyer KC. Lung infections and aging. Ageing Res Rev. 2004;3:55-67.
4. Rivera C, Falcoz PE, Bernard A, Thomas PA, Dahan M. Surgical management and outcomes of elderly patients with early stage non-small cell lung cancer: a nested case-control study. Chest. 2011;140:874-80.

5. Mery CM, Pappas AN, Bueno R, Colson YL, Linden P, Sugarbaker DJ, et al. Similar long-term survival of elderly patients with non-small cell lung cancer treated with lobectomy or wedge resection within the surveillance, epidemiology, and end results database. Chest. 2005;128:237-45.

6. Detillon D, Veen EJ. Postoperative outcome after pulmonary surgery for non-small cell lung cancer in elderly patients. Ann Thorac Surg. 2018;105:287-93.

7. Fernandez FG, Furnary AP, Kosinski AS, Onaitis MW, Kim S, Boffa D, et al Longitudinal follow-up of lung cancer resection from the Society of Thoracic Surgeons General Thoracic Surgery Database in patients 65 years and older. Ann Thorac Surg. 2016;101:2067-76.

8. Onaitis MW, Furnary AP, Kosinski AS, Kim S, Boffa D, Tong BC, et al. Prediction of long-term survival after lung cancer surgery for elderly patients in the Society of Thoracic Surgeons General Thoracic Surgery Database. Ann Thorac Surg. 2018; 105:309-16.

9. Wang Y, Wu N, Zheng Q, Wang J, Yan S, Li S, et al. Prediction of surgical outcome by modeling based on risk factors of morbidity after pulmonary resection for lung cancer in older adults. Ann Thorac Surg. 2016;102:971-8. 